\title{
PERSISTÊNCIA NO TRATAMENTO COM MEDICAMENTOS BIOLÓGICOS PARA ARTRITE PSORÍACA
}

Introdução: A artrite psoriásica (AP) é uma doença inflamatória crônica que pode acometer múltiplas articulações e está associada a psoríase. O tratamento da AP com medicamentos biológicos no Sistema Único de Saúde (SUS) foi iniciado em 2010 com a inclusão de adalimumabe, etanercepte e infliximabe (anti-TNF). Métodos: Foi construída uma coorte histórica por meio de pareamento determinístico-probabilístico das bases de dados do Departamento de Informática do SUS. A descontinuação no tratamento foi definida como ausência de dispensação após 90 dias da última dispensação. O tempo de persistência no tratamento foi calculado como o tempo entre a primeira e a última dispensação, acrescido de um período de posse do medicamento de 30 dias para adalimumabe e etanercepte, e de 30 (indução) e 60 dias (manutenção) para infliximabe. A proporção de indivíduos persistentes foi avaliada aos 6, 12, 18 e 24 meses. A persistência no tratamento foi descrita por meio de curvas de Kaplan-meier e comparada por meio do teste de log-rank. Os preditores de descontinuação no tratamento foram verificados por meio de regressão de COX. Resultados: 11.008 pacientes foram analisados. O adalimumabe (51\%) foi 0 medicamento mais utilizado. A persistência geral no tratamento foi de 78,1\% em 6 meses, 56,5\% em 12 meses, 44,3\% em 18 meses e 37,6\% em 24 meses. Indivíduos em uso de adalimumabe apresentaram maior persistência em relação à etanercepte e infliximabe $(p<0,05)$. Os preditores de não persistência foram indivíduos do sexo feminino, mais jovens, residentes nas regiões Norte e Nordeste, em uso de infliximabe e etanercepte e com maior índice de Comorbidade de Charlson. Conclusão: A persistência no tratamento reduziu ao longo do tempo e foi maior nos indivíduos em uso de adalimumabe. As desigualdades regionais, o anti-TNF em uso, a idade, a presença de comorbidades e o sexo influenciaram na persistência no tratamento.

Palavras-chave: artrite psoriásica; Sistema Único de Saúde, medicamentos biológicos 


\section{MEDICATION PERSISTENCE WITH BIOLOGICAL DRUGS FOR PSORIATIC ARTHRITIS IN BRAZIL}

Introduction: Psoriatic arthritis (PsA) is a chronic inflammatory disease that can affect multiple joints and is associated with psoriasis. Treatment of PsA with biological drugs in the Unified Health System (SUS) began in 2010 with the inclusion of adalimumab, etanercept, and infliximab. Methods: A historical cohort was built through deterministic-probabilistic linkage of the databases of the SUS Department of Informatics. Discontinuation of treatment was defined as no dispensation 90 days after the last dispensation. The time of medication persistence was calculated as the time between the first and last dispensation, plus a grace period of 30 days for adalimumab and etanercept, and 30 (induction) and 60 days (maintenance) for infliximab. The proportion of persistent individuals was assessed at 6,12 , 18 and 24 months. Medication persistence was described using KaplanMeier curves and compared using the log-rank test. Predictors of treatment discontinuation were verified by COX regression. Results: 11,008 patients were analyzed. Adalimumab (51\%) was the most commonly used drug. Medication persistence was $78.1 \%$ at 6 months, $56.5 \%$ at 12 months, $44.3 \%$ at 18 months and $37.6 \%$ at 24 months. Individuals taking adalimumab had higher persistence than etanercept and infliximab $(p<0.05)$. Predictors of non-persistence were female sex, younger patients, to live in the Northeastern and Northern regions of the country, to use infliximab and etanercept, and to have a higher Charlson Comorbidity Index. Conclusion: Medication persistence decreased over time and was higher in individuals taking adalimumab. Regional inequalities, anti-TNF in use, age, presence of comorbidities and gender influenced the medication persistence.

Keywords: psoriatic arthritis, Unified Health System, biological drugs 